Wibowo, Handayani dan Lestari / 2017

\title{
STRATEGI BERSAING PERUSAHAAN DAN KINERJA PERUSAHAAN
}

\author{
Seto Sulaksono Adi Wibowo ${ }^{1}$ \\ * Akuntansi Manajerial, Manajemen Bisnis, Politeknik Negeri Batam \\ *seto@polibatam.ac.id ${ }^{1}$ \\ Yosi Handayani $^{2}$ \\ * Akuntansi, Manajemen Bisnis, Politeknik Negeri Batam \\ *yosi@polibatam.aca.id ${ }^{21}$ \\ Ade Rika Lestari ${ }^{3}$ \\ * Akuntansi Manajerial, Manajemen Bisnis, Politeknik Negeri Batam \\ *aderikl@yahoo.com ${ }^{3}$
}

\begin{abstract}
This research sets out to examine about effect of (1) ratio SG\&A/Sales on company performance (2) ratio Sales/CoGS on company performance in which variable ratio of SG\&A/Sales and Sales/CoGS used to measure generic strategy of product differentiation strategy. Population in this research is manufacturing sector company from 2012 - 2014 as many as 120 samples. This research is using purposive sampling technique to collect samples. The analysis tool used is simple regression with coefficient determination and t statistic. The results of this research concludes that generic strategy of product differentiation strategy as measured by variable SG\&A/Sales and Sales/CoGS effect on company performance as measured by net profit margin (NPM).The limitations of this research are: (1) This research is confined to manufacturing sector companies (2) On average in the annual report and financial statement companies provide information about the complete lack of research and development costs. Recommendation in this research include: (1) For future researcher should take samples of all sectors listed in Indonesia Stock Exchange (2) Adding other variables relating to generic strategies and performance of company.
\end{abstract}

Keywords: generic strategy, company performance, product differentiation strategy, cost leadership strategy, net profit margin, manufacturing sector company.

\section{Pendahuluan}

Kemajuan ekonomi global dan teknologi yang cepat menimbulkan persaingan usaha yang sangat ketat di berbagai sektor. Perkembangan perusahaan yang semakin pesat menimbulkan persaingan yang semakin tinggi, sehingga perusahaan membutuhkan strategi untuk mempertahankan keberadaannya untuk jangka waktu yang panjang. Pengelolaan manajemen strategis merupakan proses penting bagi entitas bisnis. Sebuah perusahaan yang dikategorikan sukses apabila bisa memenangkan persaingan.

Dasar dari pengembangan strategi bersaing mencakup pemikiran bagaimana perusahaan akan bersaing dan memberikan pertahanan yang baik untuk menghadapi persaingan global, sedangkan perusahaan yang tidak merespon kondisi persaingan secara efektif maka tidak akan berhasil dan mengalami kemunduran (Porter, 1996).
Strategi generik merupakan salah satu strategi yang sering digunakan oleh perusahaan untuk bersaing dalam industri sejenis maupun berbeda jenis. Strategi bersaing generik bertujuan untuk menciptakan posisi yang menguntungkan dan kekuatan pada persaingan industri. Strategi-strategi generik yang telah ditetapkan selanjutnya digunakan untuk menetapkan hal-hal yang berkaitan dengan perencanaan, perumusanan, dan pengimplementasian kegiatan operasional, sehingga perusahaan mempunyai arah yang jelas dalam upaya mencapai tujuan. Porter (1980) mengemukakan bahwa terdapat tiga jenis strategi generik yang kompetitif yaitu strategi kepemimpinan biaya, diferensiasi produk dan strategi fokus.

Dua jenis strategi generik yang sering diimplementasikan oleh perusahaan khususnya perusahaan manufaktur yaitu strategi kepemimpinan biaya dan diferensiasi produk serta kedua jenis strategi 
ini sangat berbeda baik dilihat dari sasaran pelanggan maupun secara penerapannya. Strategi fokus dan strategi kepemimpinan biaya tidak digunakan didalam penelitian ini, hal ini disebabkan karena strategi fokus hanya digunakan untuk segmen pasar tertentu saja dan tidak digunakan untuk perusahaan manufaktur secara keseluruhan dan strategi kepemimpinan biaya juga sedikit digunakan dalam perusahaan manufaktur khususnya di Indonesia. Selain itu strategi fokus ditujukan untuk melayani kebutuhan konsumen yang jumlahnya relatif kecil dan segmen pasar yang sempit, sehingga strategi fokus jarang dipakai oleh perusahaan manufaktur secara keseluruhan.

Porter (1980) menyajikan kerangka strategi generik yaitu strategi kepemimpinan biaya dan diferensiasi produk yang digunakan untuk mencapai keunggulan kompetitif. Namun, strategi diferensiasi produk lebih banyak digunakan dalam perusahaan manufaktur, hal ini disebabkan karena strategi diferensiasi produk lebih fleksibel mengikuti perkembangan zaman sehingga mampu untuk bertahan dalam persaingan dibandingkan dengan strategi kepemimpinan biaya. Strategi diferensiasi produk berfokus terhadap pencarian peluang pasar untuk menawarkan produk yang unik kepada pelanggan, melakukan peluncuran produk baru, serta melakukan pengembangan dan inovasi produk, sehingga produk menjadi unik daripada pesaing. Menurut Porter (1985) mengemukakan bahwa inovasi merupakan sarana keunggulan kompetitif untuk mencapai kesuksesan. Strategi diferensiasi menawarkan pencapaian keuntungan yang tinggi, tetapi perusahaan manufaktur yang menerapkan strategi diferensiasi harus masih berhati-hati dalam menyeimbangkan biaya yang dikeluarkan untuk menghasilkan produk yang unik.

Motivasi peneliti menguji pengaruh strategi generik terhadap kinerja perusahaan adalah untuk mendapatkan hasil empiris yang dilakukan peneliti terdahulu dikarenakan beberapa perbedaan terhadap hasil yang ditemukan. Hasil uji empiris mengenai penerapan strategi generik khususnya strategi diferensiasi produk akan membantu perusahaan sebagai bahan evaluasi apakah perusahaan sudah menerapkan strategi generik khususnya strategi diferensiasi produk yang sesuai dengan arah dan tujuan perusahaan manufaktur. Penelitian ini merupakan replikasi dari penelitian Chang et al (2015). Penelitian tersebut menguji hubungan antara posisi strategi yang diukur dengan strategi kepemimpinan biaya dan diferensiasi produk terhadap efisiensi produksi. Hasil penelitian yang menggunakan data panel menunjukkan bahwa hubungan yang positif dan signifikan antara strategi kepemimpinan biaya dengan efisiensi produksi, sedangkan terhadap strategi diferensiasi produk menunjukkan hasil yang negatif terhadap efisiensi produksi.

Penelitian ini memiliki beberapa perbedaan dengan penelitian Chang et al (2015). Penelitian ini menggunakan variabel dependen untuk mengukur kinerja perusahaan dengan menggunakan Net Profit Margin (NPM). Menggunakan net profit margin untuk mengetahui sejauh mana perusahaan mengelola kinerjanya untuk peningkatan profitabilitas. Apabila semakin tinggi nilai net profit margin maka semakin baik juga kondisi perusahaan untuk bertahan dalam persaingan. Penelitian ini hanya menggunakan 2 variabel independen untuk mengukur strategi diferensiasi produk yaitu rasio total biaya penjualan dan biaya administrasi dan umum terhadap penjualan (SG\&A/Sales) dan rasio penjualan terhadap harga pokok penjualan (Sales/COGS).

Berdasarkan uraian yang sudah disampaikan diatas, maka perumusan masalah dalam penelitian ini adalah apakah terdapat pengaruh strategi diferensiasi produk yang diukur dengan rasio SG\&A/Sales terhadap kinerja perusahaan, dan apakah terdapat pengaruh strategi diferensiasi produk yang diukur dengan rasio Sales/COGS terhadap kinerja perusahaan. Penelitian ini mengukur kinerja perusahaan dengan menggunakan net profit margin (NPM), khususnya sektor manufaktur yang terdaftar di BEI dari tahun 2012-2014.

\section{Kajian Pustaka dan Pengembangan Hipotesis Kajian Pustaka Strategi Perusahaan}

Strategi merupakan upaya dan langkah-langkah yang digunakan perusahaan untuk mencapai tujuan yang telah ditentukan. Strategi bisnis adalah acuan dan pedoman bagi perusahaan untuk bersaing dan bertahan. Apabila perusahaan yang memilih dan berhasil mengimplementasikan strategi kepemimpinan biaya atau diferensiasi produk, akan berada dalam posisi untuk secara efektif menangani kompetitif kekuatan yang menentuka keberhasilan dalam suatu industri (Porter, 1980). 
Persaingan yang semakin ketat membuat perusahaan manufaktur mencari strategi yang tepat. Strategi generik merupakan strategi yang terkoordinasi yang dirancang untuk menyediakan nilai kepada pelanggan dan mendapatkan keunggulan kompetitif. Salah satu strategi generik yang paling sering digunakan adalah strategi diferensiasi produk.

\section{Diferensiasi Produk}

Diferensiasi produk lebih menekankan keunggulan produk, pengembangan serta pengenalan produk baru ke pangsa pasar dengan tujuan untuk menemukan keunikan tersendiri terhadap produknya. Pencapaian strategi ini ditekankan pada keunikan produk, tambahan features, kenyamanan, dan tambahan lainnya pada produk agar sulit ditiru oleh pesaing. Menurut Kartajaya (2004), terdapat tiga syarat acuan penentu diferensiasi produk seperti menciptakan excellent value kepada pelanggan sehingga perbedaan tersebut memiliki makna dimata pelanggan, keunggulan bersaing yang menimbulkan perbedaan dengan pesaing dan perbedaan tersebut mencerminkan keunggulan dari penawaran perusahaan, serta memiliki keunikan agar perusahaan mampu bertahan dan tidak mudah untuk ditiru oleh pesaing lainnya. Porter (1980) mengemukakan bahwa strategi diferensiasi harus tersusun atas sekumpulan aktivitas yang saling berhubungan dan saling menunjang konstruktif dengan yang lainnya.

Porter (1980) strategi diferensiasi fokus pada pembuatan produk, penawaran serta pelayanan yang unik kepada pelanggan. Menggunakan strategi diferensiasi produk lebih baik untuk jangka panjang karena unik dan sulit untuk ditiru (Banker et al, 2014). Faktor kunci dari strategi diferensiasi produk adalah perusahaan mengenalkan produk baru, melakukan pengembangan dan inovasi secara terus menerus, memberikan layanan yang prima dan berbeda untuk pelanggan sehingga terlihat berbeda dengan persaing dalam industri yang sejenis maupun yang tidak sejenis.

Dengan strategi ini perusahaan manufaktur mampu mempertahankan kondisi perusahaan dimana perusahaan memiliki keunikan yang lebih tahan lama dan sulitnya pesaing untuk meniru. Menurut Porter langkah-langkah yang dapat ditempuh untuk menentukan landasan bagi strategi diferensiasi produk seperti menentukan pelanggan, mengidentifikasi rantai nilai, menentukan susunan peringkat kriteria pembelian pelanggan, menilai sumber keunikan yang sudah ada, memilih konfigurasi aktivitas nilai yang menciptakan diferensiasi produk paling bernilai bagi pelanggan terhadap biaya diferensiasi, menguji daya tahan strategi diferensiasi produk yang telah ditentukan, serta menurunkan biaya dalam aktivitas yang tidak mempengaruhi bentuk diferensiasi produk yang telah dipilih.

\section{Net Profit Margin}

Net profit margin (NPM) termasuk ke dalam kelompok rasio profitabilitas dan digunakan untuk mengukur kinerja perusahaan. Semakin besar nilai net profit margin (NPM) maka kinerja suatu perusahaan semakin produktif dan menunjukkan semakin baik juga dalam pencapaian laba yang tinggi. Selain menilai dan mengevaluasi laba, net profit margin (NPM) juga menunjukkan kemampuan perusahaan dalam mengendalikan biaya-biaya sehingga menciptakan kondisi yang efisiensi.

Efektifitas dan efisiensi dalam menjalankan kegiatan rutin operasional perusahaan sangat penting terutama dalam mengendalikan biaya sehingga tidak terjadi pemborosan. Perusahaan memilih strategi yang tepat guna mendukung tujuan efisiensi sehingga perusahaan mencapai tingkat laba yang diharapkan.

\section{Penelitian-penelitian sebelumnya}

Penelitian Banker et al (2014) dengan menggunakan analisis data panel menunjukkan bahwa strategi kepemimpinan biaya dan diferensiasi produk berpengaruh signifikan terhadap kinerja perusahaan tetapi perusahaan yang menerapkan strategi diferensiasi produk lebih baik untuk jangka panjang dibandingkan dengan strategi kepemimpinan biaya karena strategi kepemimpinan biaya bersifat hanya sementara.

Penelitian Jahromi et al (2014) menunjukkan bahwa rasio penjualan terhadap aset sebagai variabel strategi kepemimpinan biaya memiliki hubungan negatif terhadap kinerja perusahaan yang diukur dengan return on assets (ROA), hal ini menunjukkan jika pemilihan strategi kepemimpinan biaya sedikit memiliki pengaruh terhadap pencapaian laba terhadap aset.

Penelitian Rustamblin et al (2013) menunjukkan hasil bahwa penerapan strategi diferensiasi produk berpengaruh signifikan terhadap kinerja bank umum, sedangkan untuk strategi kepemimpinan biaya dan strategi terpadu tidak 
memiliki hubungan yang signifikan terhadap kinerja bank umum.

Penelitian Josiah et al (2013) menunjukkan hasil bahwa strategi kepemimpinan berpengaruh terhadap kinerja perusahaan gas. Sedangkan Spencer et al (2009) menggunakan pengukuran kinerja perusahaan yaitu secara keuangan dan non keuangan. Hasil penelitian menunjukkan bahwa terdapat hubungan positif antara strategi diferensiasi dan kinerja perusahaan melalui peran mediasi dari kinerja non keuangan dan keuangan.

\section{Pengembangan hipotesis}

Konsep dasar dari strategi diferensiasi produk adalah inovasi. Selera konsumen yang berubah-ubah mengakibatkan perlunya perubahan, pengembangan serta menawarkan variasi dari produk. Strategi ini tidak hanya mengubah produk menjadi unik tetapi juga mempengaruhi pelanggan dan menambah nilai pelanggan serta menawarkan nilai dan manfaat produk yang lebih besar daripada pesaing. Porter (1985) strategi kepemimpinan biaya perlu mengendalikan biaya dengan ketat dan mengurangi biaya inovasi terhadap produk. Hal ini tentu saja membuat perusahaan meminimalkan kreativitas dan inovasi dalam mengembangkan produk sehingga perusahaan bisa mengalami kemunduran akibat tidak mengembangkan produk dan melakukan inovasi.

Rasio SG\&A/Sales digunakan untuk mengukur strategi diferensiasi produk. Alokasi yang lebih tinggi untuk SG \& A mencerminkan upaya yang lebih baik untuk mencapai keunggulan strategi dan pencapaian laba. Penggunaan rasio ini dapat memberikan informasi mengenai berapa pengeluaran yang telah dikeluarkan oleh perusahaan yang menerapkan strategi diferensiasi produk untuk memperoleh penjualan yang tinggi.

Rasio Sales/CoGS digunakan untuk mengukur strategi diferensiasi produk. Rasio ini digunakan untuk melihat kemampuan perusahaan yang menerapkan strategi diferensiasi produk untuk membuat profit margin menjadi tinggi. Perusahaan manufaktur yang menerapkan strategi diferensiasi produk memiliki harga pokok penjualan yang lebih tinggi karena selalu melakukan inovasi dan pengembangan, sehingga rasio ini mengukur perbandingan tingkat penjualan dan harga pokok penjualan terhadap pencapaian laba perusahaan tersebut. Berdasarkan uraian yang telah dijelaskan, maka hipotesis yang dapat disimpulkan tentang pengaruh strategi generik khususnya strategi diferensiasi terhadap kinerja perusahaan:

$\mathrm{H}_{1}$ : Rasio SG\&A/Sales berpengaruh terhadap kinerja perusahaan.

$\mathrm{H}_{2}$ : Rasio Sales/CoGS berpengaruh terhadap kinerja perusahaan.

\section{Metode Penelitian}

\section{Rancangan Kegiatan}

Penelitian ini merupakan penelitian induktif yang menyimpulkan hasilnya berdasarkan pada angkaangka pengujian statistik dari data-data yang telah dikumpulkan.

\section{Ruang Lingkup atau Objek}

Objek yang diteliti adalah laporan tahunan perusahaan pada sektor manufaktur (sektor industri dasar dan kimia, sektor aneka industri, dan sektor industri barang konsumsi) yang terdaftar di BEI pada tahun 2012-2014.

\section{Bahan}

Penelitian ini hanya menggunakan data sekunder, yaitu laporan tahunan yang telah diaudit dan terdaftar di BEI.

\section{Tempat}

Tempat penelitian dilakukan di Indonesia, khususnya di kota Batam. Hal ini bisa dilakukan karena jenis data yang digunakan adalah data sekunder yang diambil dari website BEI nasional.

\section{Teknik Pengumpulan Data}

Dalam penelitian ini menggunakan teknik pengumpulan data berupa basis data. Basis data yang digunakan berasal dari sumber Bursa Efek Indonesia (BEI) atau yang terdapat dalam situs resmi www.idx.go.id berupa laporan tahunan dan keuangan perusahaan yang telah diaudit khususnya perusahaan manufaktur selama 2012-2014. Sampel yang dipilh juga harus memenuhi kriteria yang ditetapkan (purposive sampling), seperti: perusahaan manufaktur yang terdaftar di Bursa Efek Indonesia selama periode 2012-2014, perusahaan manufaktur yang menerbitkan laporan keuangannya dalam mata uang rupiah dan menyajikan laporan tahunan setiap tahunnya serta laporan keuangan yang telah diaudit, perusahaan manufaktur yang menerapkan strategi generik yaitu strategi diferensiasi produk yang dapat dilihat dari 
laporan tahunan perusahaan seperti visi dan misi, laporan direksi dan komisaris, kebijakan strategi yang ditentukan, serta analisa manajemen, perusahaan mengalami laba dalam periode 2012-2014, serta perusahaan memiliki data-data lengkap untuk pengukuran variabel yang dibutuhkan penelitian.

\section{Definisi Operasional Variabel Net Profit Margin (NPM)}

Variabel net profit margin digunakan untuk mengukur kinerja perusahaan. Tandelilin (2010) menunjukkan bahwa semakin besar rasio ini, berarti semakin baik perusahaan dalam menghasilkan laba serta memperlihatkan juga bagaimana teknik perusahaan dalam mengontrol biaya agar efisien atau menunjukkan seberapa efisien perusahaan dalam mengelola penjualannya dalam mencapai laba. Perhitungan NPM bisa dilakukan dengan rumus berikut (Agustina \& Sumartio, 2014):

\section{NPM = Net Income/Sales}

\section{Strategi Generik (Strategi Diferensiasi Produk)}

Dalam penelitian Balsam et al (2011) dan Chang et al (2015) variabel independen yang digunakan untuk mengukur strategi diferensiasi produk sebagai berikut:

1. SG\&A/Sales adalah rasio biaya penjualan, biaya administrasi dan umum terhadap penjualan. Variabel ini menjelaskan tentang investasi perusahaan untuk membedakan produk yang ditawarkan oleh para pesaingnya. Perusahaan yang menggunakan strategi diferensiasi produk mengeluarkan biaya yang lebih daripada kepemimpinan biaya dan fokus seperti biaya iklan, pelayanan yang lebih kepada pelanggan, dan biaya-biaya lainnya terkait untuk memberikan sesuatu yang unik kepada pelanggan dan tingkat penjualan yang lebih tinggi.

2. Sales/CoGS merupakan rasio penjualan bersih terhadap harga pokok penjualan. Perusahaan yang menerapkan strategi kepemimpinan biaya berusaha meminimalkan harga pokok penjualan dibandingkan dengan perusahaan yang menerapkan srategi diferensiasi produk.

\section{Ukuran Perusahaan (Firm Size)}

Ukuran perusahaan merupakan salah satu skala yang dapat menilai besar atau kecil perusahaan menurut berbagai cara antara lain aset perusahaan. berikut merupakan formula dari ukuran perusahaan (Fachrudin, 2011):

Ukuran Perusahaan $=$ Ln Total Assets

\section{Current Ratio (CR)}

Rasio ini digunakan untuk mengukur ukuran likuiditas perusahaan. Selain itu rasio ini juga mengukur kemampuan perusahaan dalam membayar kewajiban jangka pendek. Rumus CR dihitung dengan cara berikut (Julduha \& Kusumawardhani, 2013):

\section{CR = Current Assets/Current Liabilities}

\section{Teknik Analisis}

Teknik analisis data yang digunakan dalam penelitian ini adalah analisis regresi sederhana untuk menentukan pengaruh dari variabel independen terhadap variabel dependen. Adapun uji yang digunakan dalam penelitian ini antara lain: uji statistik deskriptif, uji asumsi klasik, uji hipotesis.

\section{Hasil dan Pembahasan Statistik deskriptif}

Tabel 1

Hasil Statistik Deskriptif

\begin{tabular}{|c|c|c|c|c|}
\hline Variabel & Mean & Max & Min & St. D \\
\hline NPM & 0.0645 & 0.18 & 0.000 & 0.047 \\
\hline SG\&A/Sales & 0.1516 & 0.52 & 0.008 & 0.124 \\
\hline Sales/CoGS & 1.3972 & 2.49 & 0.994 & 0.344 \\
\hline Size & 28.427 & 33.09 & 25.32 & 1.849 \\
\hline Cur. Ratio & 4.1055 & 247.4 & 0.548 & 22.45 \\
\hline Sampel & \multicolumn{5}{|c|}{120} \\
\hline
\end{tabular}

Sumber: data olahan SPSS

Tabel diatas menunjukkan hasil statistik deskriptif dari 120 sampel amatan yang menyatakan bahwa variabel net profit margin (NPM) memiliki nilai rata-rata (mean) adalah 0.0645 . Hal ini berarti bahwa rata-rata perolehan laba bersih adalah sebesar $6.45 \%$ dari penjualan bersih yang dicapai perusahaan. Variabel SG\&A/Sales memiliki nilai rata-rata (mean) 0.1516. Hal ini berarti bahwa rata-rata sampel perusahaan manufaktur melaporkan beban penjualan dan beban administrasi \& umum sebesar $15.17 \%$ dari total penjualan bersih yang dimiliki oleh perusahaan manufaktur. Variabel Sales/CoGS memiliki nilai rata- 
rata (mean) 1.397. Hal ini berarti bahwa rata-rata sampel perusahaan manufaktur mampu memperoleh penjualan sebesar $139.7 \%$ dari harga pokok penjualan yang dicapai oleh perusahaan. Variabel control ukuran perusahaan (size) dan current ratio masing-masing memiliki rata-rata (mean) 28.427 dan 4.1055.

\section{Uji Normalitas}

Hasil uji normalitas menunjukkan bahwa nilai variabel Asymp. Sig sebesar $0.198>0.05$, sehingga dapat disimpulkan bahwa data berdistribusi normal dan layak untuk digunakan dalam penelitian.

\section{Uji Multikolinearitas}

Ada atau tidaknya multikolinearitas dapat dilihat dari nilai VIF (Variance Inflation Factor). Apabila nilai VIF <10 menunjukkan data penelitian bebas dari multikolinearitas (Ghozali, 2012). Berdasarkan hasil uji diketahui bahwa nilai VIF pada masing-masing variabel bernilai <10, sehingga disimpulkan model regresi dalam penelitian ini bebas dari multikolinearitas.

\section{Uji Autokorelasi}

Pengujian ini menggunakan nilai uji DurbinWatson (DW). Hasil uji menunjukkan bahwa nilai $\mathrm{d}$ hitung sebesar 2.050 dan nilai du pada tabel Durbin Watson (DW) dengan sampel (n) 120 dan jumlah variabel 4 maka angka yang diperoleh du $=1.7715$ dan 2.2285. Kesimpulan berdasarkan hasil uji autokorelasi berdasarkan kriteria yang telah ditentukan adalah menunjukkan bahwa $1.7715<2.050<2.2285$, sehingga data penelitian tidak terjadi autokorelasi.

\section{Uji Heterokedastisitas}

Ada atau tidaknya heteroskedastisitas diketahui dengan melakukan uji Geljser. Kriteria pengambilan keputusan yaitu nilai signifikan $>0.05$. Berdasarkan hasil uji menunjukkan bahwa signifikansi masingmasing variabel diatas 0.05 sehingga disimpulkan bahwa tidak terdapat heterokedastisitas.

\section{Uji Hipotesis}

Hipotesis pertama $\left(\mathrm{H}_{1}\right)$ menyatakan bahwa rasio SG\&A/Sales untuk mengukur strategi diferensiasi produk berpengaruh terhadap kinerja perusahaan.
Tabel 2

Hasil Uji Hipotesis 1

\begin{tabular}{|l|c|c|l|}
\hline \multicolumn{1}{|c|}{ Model } & \multicolumn{1}{c|}{ B } & \multicolumn{1}{c|}{$\mathrm{t}$} & \multicolumn{1}{c|}{ Sig } \\
\hline Constant & -0.352 & -5.805 & 0.000 \\
\hline SG\&A/Sales & 0.138 & 4.716 & 0.000 \\
\hline Size & 0.014 & 6.631 & 0.000 \\
\hline CR & 0.000 & 1.345 & 0.181 \\
\hline Adj R ${ }^{2}$ & \multicolumn{3}{|c}{0.313} \\
\hline
\end{tabular}

Sumber: data olahan SPSS

Berdasarkan hasil uji tersebut diketahui nilai konstanta sebesar -0.352. Hal ini menunjukkan bahwa jika variabel independen SG\&A/Sales bernilai 0, maka variabel net profit margin (NPM) mengalami penurunan sebesar 0.352. Nilai koefisien regresi variabel SG\&A/Sales sebesar 0.138. Hal ini menunjukkan bahwa setiap penambahan satu nilai SG\&A/Sales maka nilai kinerja perusahaan bertambah sebesar 0.138 .

Nilai signifikansi dibawah 0.05 menandakan bahwa $\mathrm{H}_{1}$ terdukung. Hal ini berarti variabel rasio SG\&A/Sales sebagai pengukur strategi generik yaitu strategi diferensiasi produk berpengaruh terhadap kinerja perusahaan. Nilai koefisien determinasi sebesar 0.313 menunjukkan bahwa strategi generik yaitu strategi diferensiasi produk sebagai variabel independen dan variabel kontrol yaitu ukuran perusahaan (firm size) dan current ratio dapat menjelaskan kinerja perusahaan sebesar $31.3 \%$ sedangkan $68.7 \%$ sisanya dijelaskan oleh variabel lain diluar model regresi.

\section{Tabel 3}

Hasil Uji Hipotesis 2

\begin{tabular}{|l|r|r|l|}
\hline \multicolumn{1}{|c|}{ Model } & \multicolumn{1}{c|}{ B } & \multicolumn{1}{c|}{ t } & \multicolumn{1}{c|}{ Sig } \\
\hline Constant & -0.404 & -7.524 & 0.000 \\
\hline Sales/CoGS & 0.074 & 8.032 & 0.000 \\
\hline Size & 0.013 & 7.092 & 0.000 \\
\hline CR & 0.000 & 2.037 & 0.044 \\
\hline Adj R ${ }^{2}$ & \multicolumn{3}{|c|}{0.474} \\
\hline
\end{tabular}

Sumber: data olahan SPSS

Hipotesis kedua $\left(\mathrm{H}_{2}\right)$ menyatakan bahwa variabel Sales/CoGS sebagai pengukur strategi generik yaitu strategi diferensiasi produk berpengaruh terhadap kinerja perusahaan.

Berdasarkan hasil uji diketahui nilai konstanta sebesar -0.404. Hal ini menunjukkan bahwa jika variabel independen Sales/CoGS bernilai 0, maka variabel net profit margin (NPM) mengalami 
Wibowo, Handayani dan Lestari / 2017

penurunan sebesar 0.404. Nilai koefisien regresi variabel Sales/CoGS sebesar 0.074. Hal ini menunjukkan bahwa setiap penambahan satu nilai Sales/CoGS maka nilai kinerja perusahaan bertambah sebesar 0.074 .

Nilai signifikansi dibawah 0.05 menandakan bahwa $\mathrm{H}_{2}$ terdukung. Hal ini berarti variabel rasio Sales/CoGS sebagai pengukur strategi generik yaitu strategi diferensiasi produk berpengaruh terhadap kinerja perusahaan. Nilai koefisien determinasi sebesar 0.474 menunjukkan bahwa strategi generik yaitu strategi diferensiasi produk sebagai variabel independen dan variabel kontrol yaitu ukuran perusahaan (firm size) dan current ratio dapat menjelaskan kinerja perusahaan sebesar $47.4 \%$ sedangkan $52.6 \%$ sisanya dijelaskan oleh variabel lain diluar model regresi.

\section{Simpulan}

Berdasarkan hasil penelitian dapat ditarik kesimpulan sebagai berikut:

a. Hasil pengujian $\mathrm{H}_{1}$ menunjukkan bahwa variabel SG\&A/Sales berpengaruh terhadap kinerja perusahaan yang diukur dengan net profit margin (NPM). Hal ini berarti strategi diferensiasi yang diukur dengan variabel SG\&A/Sales mempengaruhi net profit margin karena perusahaan yang menerapkan strategi diferensiasi mengeluarkan biaya yang lebih untuk membuat produk menjadi unik dari pesaing yang lainnya, hal ini bertujuan untuk meningkatkan penjualan produk agar perusahaan dapat memperoleh pencapaian laba.

b. Hasil pengujian $\mathrm{H}_{2}$ secara parsial menunjukkan bahwa variabel Sales/CoGS berpengaruh terhadap kinerja perusahaan yang diukur dengan net profit margin (NPM).

Peneliti menemukan beberapa keterbatasan yaitu: objek penelitian hanya pada perusahaan sektor manufaktur yang terdaftar di Bursa Efek Indonesia (BEI) tahun 2012-2014, sehingga tidak memasukkan sampel perusahaan yang berasal dari sektor lain. Hal ini mengakibatkan hasil penelitian ini tidak bisa digeneralisasi untuk sektor jenis perusahaan lain. Oleh karena itu disarankan pada penelitian selanjutnya bisa divariasikan jenis industrinya dan tambah tahun amatannya supaya lebih banyak data yang dimiliki.

\section{Referensi}

[1] Agustina, \& Sumartio, F. (2014). Analisa FaktorFaktor yang Mempengaruhi Pergerakan Harga Saham Pada Perusahaan Pertambangan. Jurnal Wira Ekonomi Mikroskil, Vol. 4.

[2] Balsam, S., Fernando, G. D., \& Tripathy, A. (2011). The Impact of Firm Strategy on Performance Measures Used in Executive Compensation. Journal of Business Research, 187-193.

[3] Banker, R. D., Mashruwala, R., \& Tripathy, A. (2014). Does A Differentiation Strategy Lead to More Sustainable Financial Performance than A Cost Leadership Strategy? Management Decision, Vol. 52.

[4] Chang, H., Fernando, G. D., \& Tripathy, A. (2015). An Empirical Study of Strategic Positioning and Production Efficiency. Hindawi Publishing Corporation.

[5] Fachrudin, K. A. (2011). Analisis Pengaruh Struktur Modal, Ukuran Perusahaan, dan Agency Cost Terhadap Kinerja Perusahaan. Jurnal Akuntansi dan Keuangan, Vol. 13.

[6] Ghozali, I. (2012). Aplikasi Analisis Multivariate Dengan Program IBM SPSS 20. Semarang: Badan Penerbit Universitas DiPonegoro.

[7] Jahromi, N. M., Darabi, S. A., \& Birjandi, M. (2014). The Effect Of Cost Leadership Strategy On ROA and Future Performance Of Accepted Companies in Tehran Stock Exchange. Research Journal of Finance and Accounting, Vol 5, No. 7.

[8] Josiah, N. M., \& Nyagara, N. I. (2015). Assessment of The Effect of Cost Leadership Strategy on The Performance of Liquefied Petroleum Gas Companies in Eldoret Town, Uasin Gishu County, Kenya. International Journal of Business and Management Invention, Vol 4.

[9] Julduha, N., \& Kusumawardhani, I. (2013). Pengaruh Net Profit Margin, Current Ratio, Debt to Asset Ratio, Tingkat Suku Bunga Terhadap Beta Saham Syariah Pada Perusahaan yang Terdaftar Di Jakarta Islamic Index. Jurnal Buletin Studi Ekonomi, Vol. 18. 
[10] Kartajaya, H. (2004). Positioning, Diferensiasi, dan Brand. Jakarta: PT Gramedia Pustaka Utama.

[11] Porter, M. (1980). Competitive Strategy: Techniques for Analyzing Industries and Competitors. New York: Free Press.

[12] Porter, M. (1985). Competitive Advantage. New York: Free Press.

[13] Porter, M. (1996). What is Strategy? Harvard Business Review, Vol. 74 No. 6, pp. 61-78.

[14] Rustamblin, D., Thoyib, A., \& Zain, D. (2013). Pengaruh Strategi Generik terhadap Kinerja Perusahaan. Jurnal Aplikasi Manajemen, Vol 11.

[15] Spencer, S. Y., Joiner, T. A., \& Salmon, S. (2009). Differentiation Strategy, Performance Measurement Systems and Organizational Performance: Evidence from Australia. International Journal of Business.

[16] Tandelilin, E. (2010). Portofolio dan Investasi: Teori dan aplikasi. Yogyakarta: Kanisius. 